\title{
Incubator specialization and size: Divergent paths towards operational scale
}

Magnus Klofsten, Erik Lundmark, Karl Wennberg and Nata Bank

The self-archived postprint version of this journal article is available at Linköping University Institutional Repository (DiVA):

http:/ / urn.kb.se/ resolve?urn=urn:nbn:se:liu:diva-162676

N.B.: When citing this work, cite the original publication.

Klofsten, M., Lundmark, E., Wennberg, K., Bank, N., (2020), Incubator specialization and size: Divergent paths towards operational scale, Technological forecasting \& social change, 151, 1-13. https:/ / doi.org/ 10.1016/j.techfore.2019.119821

Original publication available at:

https:// doi.org/ 10.1016/j.techfore.2019.119821

Copyright: Elsevier

http:// www.elsevier.com/

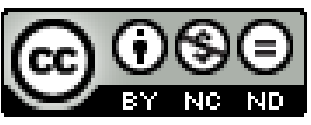


This paper should be cited as:

Klofsten, M., Lundmark, E., Wennberg, K., \& Bank, N. (2020). Incubator specialization and size: divergent paths towards operational scale, Technological Forecasting \& Social Change (https://doi.org/10.1016/j.techfore.2019.119821)

Incubator specialization and size: divergent paths towards operational scale 


\section{Incubator specialization and size}

Abstract: Research on incubators show that size is important in achieving efficiency and networking benefits for clients. However, little research has focused on what factors influence incubator size. We theorize and show partial support for size benefits to incubator specialization. Analyses of the relationship between size and four distinct specialization strategies in a sample of 96 European incubators show that incubator size is positively related to a strategic focus on universities and research institutes as recruitment channels and to a focus on sustainability, but unrelated to industry focus. Incubator size was found to be negatively related to a regional focus. While sustainability focused incubators tended to not find recruitment challenging, paradoxically, among those who did, the most frequently reported challenges were related to finding tenants that focus on sustainability. Post-hoc analyses revealed that tenants with a focus other than sustainability often dominate sustainability-oriented incubators, suggesting that sustainability may be more of a legitimating strategy than an explicit selection criterion.

Keywords: Business incubator, industry, region, university, sustainability, specialization, focus, size.

\section{Introduction}

Incubators are core actors in entrepreneurial ecosystems (Sentana et al., 2017; Lamine et al., 2016; Soetanto and Jack, 2013) that provide various forms of start-up support, such as physical space, advice-giving, and networking possibilities (Amezcua et al., 2013; Xiao and North, 2017; McAdam and Marlow, 2011; Aaboen, 2009; Autio and Klofsten, 1998; Redondo and Camarero, 2019). Through various specialization strategies such as sustainability, regional development or technology transfer, incubators also constitute instruments for policy makers seeking to steer the social and technological progress of regions and societies. Over 


\section{Incubator specialization and size}

the last few decades, the number of incubators has increased substantially and they have consequently attracted much research interest (Klofsten and Bienkowska, 2019; Lobosco et al., 2019). To date, the research on incubators has tended to focus on the design of various targeted incubator initiatives (Bergek and Norrman, 2008; Barbero et al., 2014; Hernández and Carrà, 2016) and practices to enhance start-ups support within incubators (Sung et al., 2003; Bøllingtoft and Ulhøi, 2005; Meyer, 2003; Scillitoe and Chakrabarti, 2010; Clausen and Korneliussen, 2012).

A stylized yet important finding from this body of literature is that incubator size is important in achieving efficiencies and networking benefits for their clients (Klingbeil and Semrau, 2017; Gerlach and Brem, 2015; Aerts et al., 2007; Allen and McCluskey, 1990). For example, Schwartz and Hornych (2010, p. 487) showed in a study of 150 German incubator tenants that incubator size (measured in number of tenants) was positive correlated with their tenant's engagement with customers, suppliers and technological partnerships. More recent studies also indicate that incubator size can have lasting effects on tenant firms' development (Klingbeil and Semrau, 2017; Lukeš et al., 2019).

The growing number of incubators has however made recruitment of high-quality tenants more challenging (Schwartz and Hornych, 2012). Yet, there is little research on what factors influence incubator attractiveness and subsequent size. ${ }^{1}$ This constitute a significant theoretical and practical problem for research on business incubators: While research provides guidance on how best to design incubator initiatives to support tenants, it provides little guidance on what factors influence tenant recruitment and incubator size. This lack of research is problematic not only because of the reasons behind the identified scale benefits of incubators remains opaque, but also because new incubator initiative faces recruitment

\footnotetext{
${ }^{1}$ A formal literature review (see Appendix 1) of all published studies on incubators in the 14 major entrepreneurship and innovation journals revealed but 5 papers specifically attending to incubator size or specialization, and none which sought to predict incubator size.
} 


\section{Incubator specialization and size}

challenges at the onset of their operations and attempts to reach a sufficient size may be very heterogeneous.

In this article we begin to address this research gap by investigating how specialization, a strategy frequently applied by incubators to attract tenants (Vanderstraeten and Matthyssens 2012), influences incubator size and the challenges they face in recruiting tenants. In particular, we (i) address the relationship between specialization and incubator size (measured as number of tenants), and (ii) identify major recruitment challenges facing incubators.

We theorize that incubator specialization is positively related to incubator size and test this hypothesis in a sample of 96 Northern European incubators. Since incubators can specialise along several dimensions, for instance, by focusing on specific industries, sectors, or regions (Schwartz and Hornych, 2008); recruiting through specific channels (Bergek and Norrman, 2008; Mian, 1997); or choosing specific purposes or concentrations, such as environmentally sustainable ventures (Fonseca and Chiappetta Jabbour, 2012), we test our hypothesis for four different types of specialization: industry focus, regional focus, university and research focus, and sustainability focus.

Our paper contributes to the literature by showing that specialization is related to incubator size and that specialization effects should be considered when launching new initiatives. Specifically, we find that sustainability specialization and specialization toward universities are positively related to incubator size respectively, whereas industry focus or a regional specialization are not significantly related to incubator size. Our paper also sheds light on the primary challenges faced by incubators in recruiting new tenants and we show that incubators with a sustainability specialization perceive tenant recruitment to be less challenging than incubators without such specialization. Further, post-hoc analyses revealed that although sustainability specialization is positively related to size and negatively related to recruitment challenges, the proportion of sustainability-oriented tenants in incubators with a 


\section{Incubator specialization and size}

sustainability focus tends to be low, indicating that image effects may explain at least some of the positive effect on incubator size and ease of recruitment. Thus, sustainability focus may at times be more of a legitimating strategy than an explicit selection criterion, constituting another example of the disconnect between societal needs and entrepreneurial efforts (Phillips, 2018). We elucidate and problematize these findings in light of free-text responses provided by incubator managers.

The paper is structured as follows: In the next section, we review the incubator literature and in particular the role of incubator specialization to theorize on the potential drivers of incubator size. From this we derive a set of hypotheses. We then present our data and methods, followed by quantitative and qualitative results, a discussion, and conclusions with implications for research and practice.

\section{Prior literature on incubator specialization and tenant recruitment}

In the 1980s, the emergence of incubators in Europe was accompanied by general criticism of their specialization; incubators were providers more of physical space and less of critical support tailored to the needs of start-ups undergoing early-stage development. In the eyes of Autio and Klofsten (1998, p. 33), incubators were lacking in process specialization (soft resources) and placed too much emphasis on configuration (hard resources). Subsequently, however, incubators have steadily, and relatively successfully, developed more effective and more relevant start-up support to satisfy the real needs of entrepreneurs (Soetanto and Jack, 2013; Somsuk and Laosirihongthong, 2014; Lamine et al., 2016).

Incubators today face new challenges - no less critical - of how to grow their inflow of tenants: how to best create attractiveness, find a niche in their particular entrepreneurial ecosystem (Vanderstraeten and Matthyssens, 2012), and manage relations with key stakeholders (Chan and Lau, 2005; Ejermo, 2016; McGowan et al., 2011). As shown in 


\section{Incubator specialization and size}

Kreusel et al. (2018) incubators ability to establish helix relationships (triple, quadruple or quintuple helixes) within their ecosystems will most certainly shape their capability to attract tenants and other critical resources for future sustainable development (c.f. Etzkowitz and Klofsten, 2005, Volkmann et al., 2019).

Incubators receive public funding and support in most European countries where, as elsewhere, innovation is highly desired. Incubator funding, thus, constitute a tool for funding bodies to influence the direction and speed of technological progress. To ensure effective use of public funding, however, governments require incubators to meet predetermined operational criteria; for example, incubators are often evaluated according to the number of tenants they serve (Sandström et al. 2016). To reach sufficient size, the inflow to the incubator needs to be large enough (Bank et al., 2017).

Studies have observed that recruitment strategies vary among incubators as they seek to attract entrepreneurs and their ventures and fulfil the specialization goals of the incubator (Bergek and Norrman, 2008). Selection criteria are designed to realize the objectives of the incubator (Allen and McCluskey, 1990). With flexible or broad selection criteria, the incubator is able to attract tenants from a larger pool of potential tenants; with stricter selection criteria, the incubator can better provide niched services and networks (Gabarret et al., 2014; Grimaldi and Grandi, 2005).

Despite potential drawbacks to choosing a specialization such as a heightened competitive atmosphere among tenants, benefits seem to outweigh drawbacks (e.g. Schwartz and Hornych 2008; 2010). A specific specialization makes it easy to describe the type of focused support that prospective tenants may expect and strengthens the credibility of the offer; a specific specialization also facilitates the design and provision of tailored services and domain-specific capabilities (von Zedtwitz and Grimaldi, 2006). A well-formulated specialization also attracts tenants who more likely share common interests and competencies, 


\section{Incubator specialization and size}

thus supporting knowledge transfer and networking activities. Hansen et al., (2000) argued that advantages to association through incubator tenancy are greater when tenants share common goals, and there are benefits with same-sector tenants in sharing of knowledge and technical resources (Chan and Lau, 2005). Similarly, the study by Schwartz and Hornych (2008) detailed three main benefits when incubators choose a specialization: (1) tailored facilities and equipment, (2) targeted service offerings, and (3) a profile-enhanced image. Moreover, Ebbers (2014) found that incubators with a strong network specialization both influence the tenant's opportunities to establish new business deals both also their "tertius iungens specialization" (p. 1) that provide skills in the identification of potential future business networks in the vicinity to their current business context.

Consequently, incubators that have specialised by choosing a clear specialization will increase their attractiveness and subsequently their size. This forms the conceptual logic of our baseline hypothesis, formulated as:

Hypothesis 1: Incubator specialization will be positively related to incubator size.

There are several options for incubators who want to specialise by choosing specific specialization strategies Von Zedtwitz (2003) studied inter-organisational competition between incubators using Porter's 1986 description of four dimensions: segment scope, geographical scope, industry focus, and vertical scope. Later studies have highlighted the specific impact of geographical scope and industry focus, the extent to which incubators are focusing on academic spin-offs; and whether incubators seek to facilitate sustainability among tenants (Bergek and Norrman, 2008; Barbero et al., 2012, 2014; Fonseca and Jabbour, 2012; von Zedtwitz and Grimaldi, 2006). As a follow-on to these earlier studies this article focuses on four aspects of incubator specialization: industry focus, regional focus, university and research focus, and sustainability focus: 


\section{Incubator specialization and size}

Industry focus: Incubators can choose to focus on a particular industry or a set of industries (Grimaldi and Grandi, 2005). This specialization aims to create synergies based on competencies relating to specific technologies or competitive environments (Grimaldi and Grandi 2005). Hansen et al., (2000) and Chan and Lau (2005) argue that clustering tenants from the same or similar sectors improves both knowledge and resource sharing, and the quality of premises and equipment (Schwartz and Hornych, 2008). Additionally, managers of business incubators with a defined specialization will be able to develop sector-specific knowledge and expertise as they address tenant needs, leading to a process of path-dependent experiential learning (von Zedtwitz and Grimaldi, 2006). Consequently, a formal industry focus in incubator specialization will enhance their technological and strategic competencies of by experiential learning among incubates as well as in the incubator management, leading to a first contextual hypothesis:

Hypothesis 2a: Industry focus will be positively related to incubator size.

Regional focus: Incubators can focus on a particular geographical location to tap more easily into business networks, which tend to be of a regional nature (von Zedtwitz and Grimaldi 2006). In addition, public support initiatives often have a regional focus, thus providing funding opportunities for regionally oriented incubators (M'Chirgui et al., 2018; von Zedtwitz and Grimaldi 2006). A regional focus is congruent with the idea that entrepreneurial ecosystems are geographically delimited and require some combination and leveraging of elements, such as regional knowledge sharing, institutions, markets, and infrastructure (Stuart and Sorenson 2003). Regional focus has thus been highlighted as an important factor to consider in evaluating incubators (M'Chirgui et al., 2018). By benefiting of regionallybounded social networks in attracting tenants, we argue that incubators that specialize on 


\section{Incubator specialization and size}

recruiting tenants from a particular region will be larger than incubators that do not, forming the basis of our second contextual hypothesis:

Hypothesis 2b: Regional focus will be positively related to incubator size.

University and research focus: Another theoretically plausible specialization is to locate near or in university environments and focus on recruiting tenants in knowledge-intensive areas (Lundqvist, 2014; Hayter, 2016; Soetanto and Jack, 2016; M'Chirgui et al., 2018). Mian (1996) considered linkages with universities to be a major factor in the success of incubation programs. Similarly, Autio and Klofsten (1998) recognized closeness to a university as a major success factor in the longevity of incubators. By targeting recruitment to universities and research institutes, incubators can promote the passage of new knowledge across the socalled knowledge filter, which impedes commercial applications of new knowledge (Audretsch, 2007; Klofsten et al., 2018). Incubator recruitment from universities has been noted to often attract tenants with strong technological know-how (Mian, 1996). However, due to the multitude of educational specialties inherent in a university environment, nearby incubators tend to avoid limiting tenant specialization to a particular industry or sector (Phan et al., 2005; Schwartz and Hornych, 2008). For incubators that are spatially proximate to a university environment, the pool of talent and technological spillover may be fruitful enough to generate a flow of tenants without the need for incubators to specialize in a specific industry (Sharif, 2012). Hence, we formulate a third contextual hypothesis:

Hypothesis 2c: University and research focus is positively related to incubator size.

Sustainability focus: A final but emerging notion in the literature is the focus of certain incubators on attracting or developing tenants with sustainable operations and/or business models. With sustainability we here take a broad view (Côté and Cohen-Rosenthal, 1998); 


\section{Incubator specialization and size}

incubators with a sustainability specialization, support entrepreneurs who create businesses that benefit the environment by reducing or reversing negative environmental impacts. Some studies, like the Potts (2010) study in Australia and the Fonseca and Chiappetta Jabbour (2012) study of six incubators in Brazil, show that sustainable incubators offer support similar to conventional ones: Sustainability-oriented incubators provide physical space for a set length of time, which reduces operational costs but allows time to refine a sustainable business model (Klofsten and Bienkowska, 2015). However, due to a growing consensus on the urgent necessity to green the economy and decouple economic growth from environmental pressure (Fichter et al., 2016; OECD, 2013), national and international policies that support finding solutions to fundamental challenges such as climate change, biodiversity, and water scarcity have been rapidly emerging (European Commission, 2014). Incubators with a sustainability specialization can thus capitalize on the funding currently being made available for sustainable business practices and on the substantial interest from entrepreneurs. Few studies, however, have explored sustainability specialization among incubators (Potts, 2010; Fonseca and Chiappetta Jabbour, 2012). The emerging trend of sustainability-oriented incubators offers an opportunity to examine the extent to which tenant recruitment may be fulfilled without the need to specialize in a specific industry or in a specific region. This forms the logic of our fourth and final contextual hypothesis:

Hypothesis 2d: Sustainability focus will be positively related to incubator size.

Important to note is that while there may be complementarities or substitutes in specialization, these four categories of specialization are not mutually exclusive in concept. Some combinations, however, may be less common in practice. For example, previous research suggests that university incubators tend not to focus in any one industry or sector (Phan et al., 2005), while several examples describe university-based incubators that also develop a 


\section{Incubator specialization and size}

sustainability specialization (Côté and Cohen-Rosenthal, 1998; Fonseca and Chiappetta Jabbour, 2012). This means that conceptually, each type of specialization constitutes dimensions along which incubators may choose to focus; many, however, choose to be or remain generalists.

\section{Methodology}

\subsection{Data collection and description}

A survey was sent to incubator representatives in Finland, Germany, and Sweden in the summer of 2014. The Swedish incubators were identified through the Swedish Incubators \& Science Parks (SISP) member registry; the Finnish incubators through data from the Finish Science Park Association (Tekel); and the German incubators through the German Association of Innovation, Technology and Business Incubation Centres (ADT). In total, management in 360 business incubators, comprising all active incubators listed with the three organisations at the time, received the questionnaire. The questionnaire was sent via e-mail and after one reminder generated 96 responses (Germany: 65 [response rate 22\%]; Finland: 11 [69\%]; Sweden: 20 [45\%]). The higher response rates in Finland and Sweden may stem from a greater personal access to the incubator managers in these smaller lists, where personal reminders may have been more effective.

In all three countries, incubators tend to have relatively small staffs. In Sweden, the mean number of permanent employees was 6.5; in Germany, 5.7; and in Finland, 4.0. The average number of tenants was 12 in Finland, 20 in Sweden, and 39 in Germany. Concerning industry specialization, most incubators in our study (54\%) were generalists. Among those with a particular industry specialization, the most common sectors were IT/telecom, cleantech, and manufacturing. Table 1 presents the sample characteristics and correlations of the independent variables. 


\section{Incubator specialization and size}

---- Insert Table 1 here----

\subsection{Variable definitions}

The questionnaire comprised items in three domains: Incubator characteristics (e.g., aims, ownership, and number of tenants); Tenant recruitment focus and practices (e.g., recruitment focus, profiling, and challenges); and Tenant support (e.g., type and amount of support offered to tenants).

The main dependent variable in our study is number of tenants currently in the incubator (Smilor, 1987). This variable was measured by an open question asking all incubator managers to report the number of tenants currently located in their incubator (labelled "Tenants"). In addition, we also assessed the perceived challenge associated with recruitment. This ordinal variable that measured how challenging the incubator perceived recruitments of tenants to be (labelled "Challenge" ranging from "generally not challenging", through "sometimes challenging", to "generally challenging") (e.g. Alsos et al., 2011).

The four independent variables in the study corresponded to the possible specialization strategy under investigation and comprised primary dichotomous independent variables: university/research institute focus (i.e. whether or not universities or research institutes were among the incubator's two most important recruitment channels, labelled "University"), regional focus (i.e. whether or not the incubator recruitment was focused on star-ups in the incubator's region or local area, labelled "Regional"), industry focus (i.e., whether the incubator was a generalist or focused on a specific subset of industries, labelled "Industry"); and sustainability specialization (i.e. whether or not the incubator was to a great extent profiled as green, environmental or sustainable, labelled “Sustain”) (von Zedtwitz 


\section{Incubator specialization and size}

2003). Control variables. We also included dichotomous variables for the country of origin (labelled "Sweden", "Finland", and "Germany") as control variables.

The questionnaire also contained an open-ended response item on why tenant recruitment was considered challenging (for those who had indicated that recruitment was not without challenges). Of the 64 respondents who stated that it was "sometimes" or "generally" challenging, 49 (77\%) provided free-text responses to this item. These were analysed using qualitative content analysis as described below.

\subsection{Descriptive, bivariate and multivariate analyses}

We began our analysis by constructing a correlation matrix (Table 2) between the independent variables and the number of tenants in the incubator. A few remarks on the correlations are in order. Number of tenants was positively correlated with a university and research focus $(\mathrm{r}=0.26)$ and a sustainability specialization $(\mathrm{r}=0.32)$, but negatively correlated with a regional focus $(\mathrm{r}=-0.29)$. Challenges with recruitment was negatively correlated with incubator size, which is suggestive of face validity - that smaller incubators are small precisely due to challenges with recruiting enough tenants. ${ }^{2}$ The other variable found to correlate with perceived challenges with recruitment was sustainability specialization, which had a negative correlation (-0.26). Figure 1 shows the distribution of sustainability-oriented incubators and those that are not sustainability focused (the distributions are significantly different between the groups, Mann-Whitney $U=322.0, p=0.018$ ). We then examined our hypotheses - i.e. whether each of the four types of specialization was positively related to incubator size - using ordinary least square regression (Table 2). ${ }^{3}$

\footnotetext{
${ }^{2}$ Technically, Challenges with recruitment is an ordinal variable. Note, however, that the results are, for all practical purposes, the same whether the Spearman or the Pearson correlation (which the table is based on) is applied.

${ }^{3}$ Incubators as well as any organization could be characterized by "growth thresholds" in terms temporary or permanent limitations to expand. Methodologically, this be seen as stochastic "noise" in a linear regression model by introducing heterogenous variability in incubators seeking to grow to a specific level (set for example
} 


\section{Incubator specialization and size}

---- Insert Figure 1 here----

\subsection{Content analysis of open-ended response items}

The qualitative analysis focused on the responses to the open-ended question on perceived recruitment challenges (among those who indicated that recruiting, at least sometimes, was challenging). Two independent researchers analysed the free-text responses using a conventional content analysis approach that generated groups of responses (Hsieh and Shannon, 2005). In conventional content analysis, categories and category names derive as inductive category development (Mayring, 2000). In cases of disagreement, the statements were discussed until consensus was reached. We then compared the results of the content analysis between the four types of incubator specialization, and of respondents who generally experienced tenant recruitment as challenging with those who only sometimes did so.

\section{Results}

Controlling for the other independent variables and incubator country, the regression model (Table 2) showed a clear relationship between recruitment focus and size as measured by the number of tenants in the incubator. Controlling for the other independent variables and incubator country, incubators who focus their recruitment on universities and research institutes have on average 19 more tenants than those who do not $(\beta=18.8, p<.01)$; incubators that are specialised on sustainability have on average 16 more tenants than those who are not

by the size of current premises) and then considering further growth only to the extent that the limiting supply side factor (size of current premises) can be expanded or modified. Assuming that this is true for all incubators, this would introduce a randomly distributed error term which is captured in the residual of our regression model. As we do not know to what extent this phenomenon exist or is a problem or not, it is not possible to test whether such thresholds could introduce errors that are randomly or systematically distributed across incubators. 


\section{Incubator specialization and size}

( $\beta=15.8, p<.05)$; whereas those who focus their recruitment on the region or local area of the incubator have on average 11 tenants less that those who do not $(\beta=-10.5, p<.10)$. Note, however, that the negative regression result for regional focus is statistically significant only at the $10 \%$ level. Like for the zero-order correlations, we find industry focus to be unrelated to the number of tenants in the OLS analyses. While Swedish incubators were not significantly different in size from those in the baseline group (Finish incubators), German incubators had on average 22 more tenants than the Finish ones $(\beta=25.9, p<.05)$.

Thus, our multivariate results, similarly to those suggestive in the descriptive and bivariate analyses, show support for hypotheses $2 \mathrm{c}$ and $2 \mathrm{~d}$, but not for hypotheses $2 \mathrm{a}$ and $2 \mathrm{~b}$. Thus, some types of specialization are related to incubator size, in particular for incubators that focus on recruitment at universities and research institutes or those with a sustainability specialization. Consequently, we find mixed support for hypothesis 1 . We now turn to our qualitative and post hoc analysis to shed light on the dynamics underlying our multivariate results.

\subsection{Qualitative evidence and post-hoc analysis}

The content analysis of the open-ended responses to the question on perceived recruitment challenges generated nine response categories that were not mutually exclusive. The first three categories (mentioned by more than 25 percent of the respondents) were the largest and contained responses labelled "region", "economic cycle", and "supply of entrepreneurs". Respondents who referred to the region as a main issue related to difficulties in new tenant recruitment highlighted aspects such as the size of the region, its entrepreneurship tradition, geographic location, and flow of people out of the region. For example, one respondent claimed that "The deal flow in the region is generally low". The respondents who referred to the business cycle as a main issue related to difficulties in new tenant recruitment highlighted 


\section{Incubator specialization and size}

aspects such as favourable economic conditions and the labour market (claiming that when the economy is thriving, people tend to stay in the work force and not start businesses). For example, one respondent claimed "Especially the last two years it was difficult to find new tenants. This mainly depends on the favourable economic situation". The last of the three most frequently mentioned reasons related recruitment difficulties to the supply of entrepreneurs, that is, there were too few nascent entrepreneurs available. For example, "Currently, there are very little business start-ups."

These three were followed by four groups of responses (among 15 and 20 percent of the respondents) clustered around labels such as "rigorous selection criteria", "specialization", "lack of resources", and "competition". Respondents who referred to the selection criteria implied that the challenge was not finding interested entrepreneurs, but finding ones that met their rigorous selection criteria in the screening phase. For example, one response was “difficult to find business case that we believe may succeed". Respondents who claimed a specialization generally stated that the main challenge was finding tenants who fit their profile. For example, "Specialization on certain sectors do not allow the inclusion of undertakings in other sectors". Respondents who mentioned lack of resources claimed that they lacked, for example, funding, equipment, or human resources: "[the building] is 30 years old and even older." Lastly, respondents who mentioned competition claimed that other incubators, or the availability/price of office space more generally, decreased the attractiveness of their own offer: "Competition with other incubators nearby where free space is available".

The remaining two groups had only two or three respondents each and related to the "reputation of the incubator" and the "size of the incubator". The former group claimed that the incubator was not well-enough known to attract new tenants and the latter mentioned difficulties filling the large space available to the incubator. For example, "our services are 


\section{Incubator specialization and size}

not known well enough" or "difficult to maintain the number of tenants due to the large area of the location $\left(18.000 \mathrm{~m}^{2}\right)^{\prime \prime}$.

---- Insert Table 2 here----

The qualitative data suggest that the types of challenges experienced by incubators differed depending on the level of difficulty experienced. Notably, among those who found recruitment challenging in general, the most commonly mentioned issue by far was the region (mentioned by almost $50 \%$ ), followed by the supply of entrepreneurs, the business cycle, and specialization. Those who only occasionally found recruitment to be challenging tended to mention the economic cycle, the supply of entrepreneurs, and competition as main issues. Region seemed to be much less of an issue for this group (less than 10\%).

The types of challenges also varied depending on specialization. None of the sustainability-focused managers responded that it was generally challenging to recruit tenants and less than half said it was sometimes challenging (Figure 1). The most frequently mentioned difficulty for those who experienced any challenge was specialization, because "founder[s] in the area of environmental technology are only few and represent only a very small part of the overall number of founders". The challenges experienced by the regionally focused incubators and those with an industry focus were similar to those of their counterparts (i.e., generalists with regard to industry or region). However, the incubators who recruited from universities and research institutes tended to more frequently mention challenges relating to a lack of resources compared to those who focused on other recruitment channels. For instance, one respondent mentioned that they had had to pause incubation services "because of the lack of financial resources". 


\section{Incubator specialization and size}

Overall, our qualitative evidence, combined with the post-hoc analyses of tenant profile among sustainability-oriented incubators, suggests that incubators with a sustainability specialization may benefit from branding with a sustainability focus. Examinations of the tenant profiles in the sustainability-focused incubators reveal that a large proportion of them accepted tenants who did not meet the sustainability criterion of the incubator. One explanation may be that ventures applying to incubators tend to be in a stage where their actual value proposition, business model, and so on are still uncertain. For those ventures still in development, sustainability-oriented incubators must decide whether to take a chance that the tenant will develop along sustainability lines, or that the incubator can influence tenant development in such a direction. Such an interpretation is in line with the Alsos et al., (2011) classification of potential incubator tenants as either "Ideal incubatees" (desirable tenants who fit the incubator's criteria profile) or "Actual incubatees" (tenants who primarily do not match the ideal profile, but have the potential to eventually do so). The section below discusses the implications of our study for research on incubator specialization and sustainability entrepreneurship.

Because our data allowed us to investigate the sustainability focus of the incubator tenants, we conducted a post-hoc analysis to investigate how strictly sustainability focused ventures maintained this focus when recruiting new tenants. The results revealed that only two out of 14 sustainability specialized incubators had a majority of sustainability focused tenants, with an average of only $20 \%$ sustainability focused tenants. Thus, it seems that most sustainability-oriented incubators have lax requirements concerning the focus of their tenants.

\section{Discussion and contributions}

This paper addressed the relationship between specialization and size (i.e., number of tenants) of 96 incubators in three countries and identified the major recruitment challenges they 


\section{Incubator specialization and size}

experienced. The results reveal not only significantly differences between specialist and generalist incubators along some of the studied dimensions, but also quite large differences in some cases. While the average size of the studied incubators was 32 tenants, our results show that a sustainability specialization or a focus on universities and research institutes as recruitment channels was associated with an increase of 16 and 19 tenants respectively. These results indicate that there are divergent paths towards operational scale (size) in incubators. Not all specialization strategies, however, were associated with larger incubator size. A specialization toward a particular region was associated with a reduction in the expected number of tenants: the average in this group was 11 (significant only at the $10 \%$ level). An industry focus had no significant effect on incubator size. We also found that size differed significantly between incubators across the three countries studied, and that most incubators perceived a broad range of challenges in recruiting new tenants. The type of challenges experienced seemed to vary between incubators with a defined specialization and those with no strict specialization. Studies have shown that a narrow regional and target group specialization in fact can lead to a "critical mass" problem which in turn leads to challenges in finding tenants (Bank and Kanda, 2016). In order to secure a sufficient inflow of tenants, incubators with too narrow regional or target group specialization may thus at time be prone to abandon or change their specialization (Fichter et al., 2016).

Despite the advantages of choosing an industrial or sector specialization (Schwartz and Hornych, 2008; Von Zedtwitz and Grimaldi, 2006), our study identified no significant general relationship between industry specialization and incubator size. This does not necessarily mean that all types of industry or sector specialization are unrelated to incubator size. For example, it may be that some industries are positively related to incubator size and other industries negatively related to that measure. Thus, on average, we observed no difference between incubators with and without a defined specialization toward an industry or 


\section{Incubator specialization and size}

sector. Our sample was not large enough to include variables for each specific industry in the regression model; however, post-hoc tests revealed significant zero-order correlations between incubator size and some industries (e.g., IT/telecom, culture and the arts, and the creative industries). Nevertheless, these results must be confirmed in future research as they are not robust to Bonferroni corrections (Armstrong, 2014).

Regional specialization was marginally significant in the opposite direction to our predictions; our analyses indicated a negative effect of such specialization. An explanation for this result may be that incubators with a regional focus could be more common in regions struggling with low levels of business start-up. For example, governments in such regions may be more prone to spend resources trying to stoke entrepreneurship. If so, supporting struggling regions may be the raison d'être for many of the incubators that have a specialization toward a specific region. These results may also reflect that a regional focus is not attractive to new ventures and that other types of specialization, or no specialization at all, are better choices for an incubator if size is a main concern. For example, Gabarret et al., (2014, p. 458) state that "small public incubators [...] generally depend on small cities and often face difficulties due to a lack of resources and inadequate competitiveness in comparison with well-equipped, more dynamic incubators that may sometimes be geographically close by.” Thus, while entrepreneurship depends on the local and regional context (Feldman, 2001; Audretsch and Keilbach, 2007) - and most responding incubators consider regional or national economic development to be an important aim - our results indicate that a strong focus on local ventures in the recruitment process may have a negative effect on the size of the incubator.

Focusing on recruitment from universities and research institutes had the strongest positive relationship with incubator size, indicating that this is an attractive niche. While this may be due to high demand, it may also reflect strong access to resources for this type of 


\section{Incubator specialization and size}

incubator. That access to such resources is desirable could stem from ideas about the importance of fostering knowledge spill-overs between research institutions and new ventures (Schwartz and Hornych, 2012). This argument applies to both private investors (who would be hoping for high returns) and governments (who would be aiming to support economic growth). However, our results indicate that any causal link between a university and research institute specialization and incubator size would be more likely related to demand than supply of resources. The reason is that lack of resources was the most frequently mentioned challenge in recruiting new tenants for incubators with a university and research institute specialization. The expressed lack of resources may reflect that firms from R\&D intensive sectors are highly dependent on complex equipment and other expensive resources, rather than a dearth of funding; still, resource abundance is a less likely explanation for the larger size of the incubators that choose to focus on universities and research institutes as recruitment channels.

Sustainability specialization was also related to larger incubator size, indicating that this too is an attractive niche. Interestingly, of the sustainability-focused incubators that experienced some challenges in recruiting new tenants, half of them stated that their specialization was a main challenge. Because our data allowed us to investigate the sustainability specialization of the incubator tenants, we conducted a post-hoc analysis to investigate how strictly sustainability-oriented incubators adhered to this focus in recruiting new tenants. The results revealed that sustainability-oriented incubators are often dominated by tenants that do not have green, sustainable, or environmentally friendly products and services as their core business. Thus, it seems that most sustainability-focused incubators have lax requirements concerning the sustainability specialization of their tenants. Bansal and Roth $(2000,718)$ proposed three motivations for a sustainability specialization among organisations: "competitiveness" (economic opportunities), "legitimation" (improved image), 


\section{Incubator specialization and size}

and "ecological responsibility" (ethical motives). Incubators, like other organisations, may thus adopt a sustainability specialization to strengthen their image, and a tenant may join to strengthen theirs. While a small proportion of sustainable tenants do not preclude an authentic concern for ecological responsibility, our results indicate that much of the effect (i.e., the larger size of sustainability-oriented incubators) may have more to do with legitimacy than intent concerning the actual criterion for tenant acceptance. First, incubators with a sustainability specialization may be more attractive to potential tenants because of the image effects that are conferred on their tenants, potentially increasing the intangible value of their offering to tenants versus other incubators. Second, a sustainability specialization may confer benefits from other stakeholders such as authorities, funders, and collaborators (McGowan et al., 2011; Phan et al., 2005), encouraging incubators to highlight sustainability without necessarily adopting a stricter selection criterion. If true, such window dressing would constitute another example of the disconnect between societal needs and entrepreneurial efforts (Phillips, 2018). To the extent that sustainability is a genuine goal for incubators, we propose that incubators with such a specialization adopt a focus on "greening" their tenants in terms of facilitating or encouraging sustainability thinking in their development of products and processes, rather than select tenants whose products and processes are already characterized as sustainable. Regardless of whether one adopts the cynical view of a sustainability focus as a primarily legitimacy-enhancing strategy, or the pragmatic view of sustainability specialization as a way of attracting more tenants whose development of commercial products and business processes can be subsequently influenced to become more sustainable, our results highlight the importance of distinguishing surface-level attributes from actual processes and activities conducted in incubators.

\section{Limitations and future research}




\section{Incubator specialization and size}

Despite evidence in the literature that incubator size is important in achieving efficiencies and networking benefits for tenants, no research to date which we know of has sought to model the size of incubators. Seeking to fill this research gap, our study has probed the relation of incubator specialization to incubator size in terms of tenant numbers. While our findings regarding incubator specialization and tenant recruitment provide important insights to the discussion of why incubators do or do not choose a specialization, our study also has limitations, which offer interesting avenues for further research. One potential limitation of our research design is that we have used the self-reported views of incubator representatives, which may be coloured by their wishes to be portrayed as legitimate and valid. Self-reports are, however, less problematic when factual questions, where a true value is known, are asked compared to questions involving scales explicitly involving judgement (Wikman, 2006). Number of tenants is such a factual question, which makes this limitation less problematic.

There are also limitations to the prospect of positively establishing the causality driving our findings. Incubator size is likely driven by both supply (e.g. incubators may receive different levels of funding and have a limited scope to grow due to space limitations) and demand side factors (e.g. number of tenants interested in the incubator's services). This is an issue in the study of organizational size in general. For example, in the well-researched area of new venture growth, the core dependent variable of venture size is influenced by both supply side factors (e.g. availability of and access to capital and employees, and owner/top management ambition levels) and demand side factors (e.g. demand for each firm's products and services). We cannot, given the correlational nature of our findings, establish the causal mechanisms driving the identified relationships in this study, but we can provide some informed speculation based on the additional qualitative data that we have gathered. We study both the predictors of venture size and the level and nature of the recruitment challenges faced by incubators. The findings show that smaller incubators are more likely than larger ones to 


\section{Incubator specialization and size}

find recruitment challenging (See Table 1 : $\mathrm{R}=-0.38, \mathrm{p}<0.01$ ). This suggests that demand side factors are important and influence size. Consequently, size is driven, at least in part, by incubators' ability to recruit tenants. However, supply side factors also play a role. For example, two respondents attribute their difficulties to their large available space, indicating that oversupply is a factor. As discussed in section 5, our findings also indicate that incubators may choose to recruit tenants that do not strictly fit their selection criteria to increase the number of available tenants. Disentangling the relative importance of supply and demand side factors in influencing incubator size is an important area for future research.

Another potentially limiting factor in the current study is the number of studied incubators and the specificities of the three countries, which may represent specific institutional settings where, for example, being sustainable may confer greater legitimacy in one setting than in another. Moreover, we should consider that besides the factors we considered in this study - age and location of the incubator - availability of additional funding and media attention also affect the number of interested applicants. For instance, the development stage of an incubator has a direct relationship with the resources it is able to provide for its tenants (Lalkaka and Abetti, 1999); some new incubators have limited resources due to the "liability of newness" (Stinchombe, 1965).

More fine-grained data regarding industry specialization may unearth further advantages and disadvantages when it comes to tenant recruitment in incubators. While our post-hoc analysis indicated that some industries may be positively related to size, we found no general positive effect of specialization toward any particular industry. Ideally, studies should seek to compare similar incubators, but with different industry specialization, for a "sharp test" of the specialization hypothesis.

Our results raise further research questions, specifically concerning the role of sustainability specialization, which we found was positively associated with incubator size but 


\section{Incubator specialization and size}

not necessarily (or strongly) with the sustainability focus of their tenants. Further research could seek to problematize why incubators profile themselves as sustainable but accept a large proportion of tenants that lack that focus. We suggested that a legitimacy-enhancing strategy might be a prime driver of sustainability specialization, or possibly a pragmatic wish to attract more tenants whose development of commercial products and business processes could be influenced to become more sustainable. To what extent these explanations are mutually exclusive constitutes an important avenue for future research and is interesting from a practical point of view. Policymaking on the national level is currently favourable for sustainable activities, and especially so in leading urbanized, start-up hubs like Berlin and Stockholm. Public policy affects supply and demand, and when consciously done, could encourage sustainability. Incubators with a sustainability focus are in sense supply initiatives that are supposed to supply the market with new sustainability ideas via their support of sustainability-oriented entrepreneurs. Legislation that supports business ideas and lead markets in climate-friendly sectors is vital. Such public actions to affect the demand side essentially encourage sustainable technologies with respect to less sustainable ones; thus, we approach the ideal of a global norm: of sustainable business activities conducted by managers with sustainability as a primary concern. However, if a sustainability specialization among incubators does not translate into higher numbers of sustainability-focused ventures, support structures must be reconfigured and may need to focus more on the demand side than current supply side efforts. The large sums of public funding that actually promote entrepreneurial activities via incubators is an essential reason why policymakers should inform themselves about the effectiveness of these investments.

This argument applies beyond the sustainability focus. For example, public funds are often allocated to university and regional incubators to spur technological progress, economic growth and employment. Hence, it is vital to evaluate which types of specialization have the 


\section{Incubator specialization and size}

strongest effects on the growth and development of the economy and on technological progress. While size and inflow of tenants are important issues for incubators, small regions or regions with little entrepreneurial capital (Audretsch, 2007) may be better off with a locally focused incubator, even if such incubators are likely to remain small. Thus, future research should also more clearly address incubator location when assessing the benefits and drawbacks of a regional specialization.

\section{Conclusions}

This study to the best of our knowledge the first to investigate the relationship between incubator specialization and incubator size in terms of number of tenants. While a university and research institute specialization, or a sustainability specialization, was positively related to size, a regional or an industry specialization was not. Of particular interest is that, among the incubators studied with a sustainability specialization, tenants without a sustainability focus dominated, which questions the role of sustainability specialization as an effective means by which to steer technological progress in a more sustainable direction.

\section{Acknowledgements}

We acknowledge financial support from Formas (The Swedish Research Council 253-20112152) and the German Federal Ministry of Education and Research (BMBF) (Support code 033E001) for their financial support through ECO-INNOVERA to undertake this research as part of the SHIFT project, as well as the Ragnar Söderberg foundation. We are also grateful to three reviewers, the associate editor, and to seminar participants at Macquarie University and Linköping University, and Dzamila Bienkowska, Anna Brattström, Frederic Delmar and Klaus Fichter for helpful criticism on prior versions of this paper. 


\section{Incubator specialization and size}

\section{References}

Aaboen, L., 2009. Explaining incubators using firm analogy. Technovation, 29(10), 657-670.

Aerts, K., Matthyssens, P., and Vandenbempt, K., 2007. Critical role and screening practices of European business incubators. Technovation, 27(5), 254-267.

Amezcua, A. S., Grimes, M. G., Bradley, S. W., \& Wiklund, J., 2013. Organizational sponsorship and founding environments: A contingency view on the survival of businessincubated firms, 1994-2007. Academy of Management Journal, 56(6): 1628-1654.

Alsos, G., Hytti, U., and Ljunggren, E., 2011. Stakeholder theory approach to technology incubators. International Journal of Entrepreneurial Behavior \& Research, 17(6), 607-625.

Anderson, A. R., 2005. Enacted metaphor the theatricality of the entrepreneurial process. International Small Business Journal, 23(6), 587-603.

Allen, D., McCluskey, R., 1990. Structure, policy, services, and performance in the business incubator industry. Entrepreneurship Theory and Practice (Winter), 61-77.

Armstrong, R. A., 2014. When to use the Bonferroni correction. Ophthalmic and Physiological Optics, 34(5), 502-508.

Audretsch, D. B., 2007. Entrepreneurship capital and economic growth. Oxford Review of Economic Policy, 23(1), 63-78.

Audretsch, D. B., and Keilbach, M., 2007. The theory of knowledge spill over entrepreneurship. Journal of Management Studies, 44(7), 1242-1254.

Autio, E., and Klofsten, M., 1998. A comparative study of two European business incubators. Journal of Small Business Management, 36(1), 30-43.

Bank, N., and Kanda, W., 2016. Tenant recruitment and support processes in sustainabilityprofiled business incubators. Industry and Higher Education, 30(4), 267-277.

Bank, N., Fichter, K., and Klofsten, M., 2017. Sustainability-profiled incubators and securing the inflow of tenants-the case of Green Garage Berlin. Journal of Cleaner Production Journal of Cleaner Production, 157, 76-83.

Bansal, P., and Roth, K., 2000. Why companies go green: A model of ecological responsiveness. Academy of management journal, 43(4), 717-736.

Barbero, J. L., Casillas, J. C., Ramos, A., \& Guitar, S., 2012. Revisiting incubation performance: How incubator typology affects results. Technological Forecasting and Social Change, 79(5), 888-902

Barbero, J. L., Casillas, J. C., Wright, M., and Garcia, A. R., 2014. Do different types of incubators produce different types of innovations? Journal of Technology Transfer, 39(2), $151-168$. 


\section{Incubator specialization and size}

Bergek, A., and Norrman, C., 2008. Incubator best practice: A framework. Technovation, 28(1-2), 20-28.

Bienkowska, D., Klofsten, M., 2015. Entrepreneurship support and Sustainability specialization within business incubators: A European study, paper presented at Global Cleaner Production and Sustainable Consumption Conference, Barcelona, 1-4 November 2015.

Bøllingtoft, A., and Ulhøi, J. P., 2005. The networked business incubator-leveraging entrepreneurial agency? Journal of Business Venturing, 20(2), 265-290.

Chan K.F., and Lau, T., 2005. Assessing technology incubator programs in the science park: The good, the bad and the ugly. Technovation, 25(10): 1215-1228.

Clausen, T., \& Korneliussen, T., 2012. The relationship between entrepreneurial specialization and speed to the market: The case of incubator firms in Norway. Technovation, 32(9), 560-567.

Côté, R. P., and Cohen-Rosenthal, E., 1998. Designing eco-industrial parks: a synthesis of some experiences. Journal of cleaner production, 6(3), 181-188.

Davidsson, P., Wiklund, J., 2000. Conceptual and empirical challenges in the study of firm growth. In: Davidsson, P., Delmar, F. \& Wiklund, J. (Eds.). Entrepreneurship and the Growth of Firms, pp. 39-61.

Ebbers, J. J. (2014). Networking behavior and contracting relationships among entrepreneurs in business incubators. Entrepreneurship Theory and Practice, 38(5), 1-23.

European Commission., 2014. Green action plan for SMEs: Enabling SMEs to turn environmental challenges into business opportunities. European Commission. Brussels.

Etzkowitz, H., \& Klofsten, M. (2005). The innovating region: toward a theory of knowledgebased regional development. $R \& D$ Management, 35(3), 243-255.

Feldman, M. P., 2001. The entrepreneurial event revisited: firm formation in a regional context. Industrial and Corporate Change, 10(4), 861-891.

Fichter, K., Fuad-Luke, A., Hjelm, O., Klofsten, M., Backman, M., Bergset, L., Bienkowska, D., Clausen, J., Geier, J., Hirscher, A.L., Kanda, W., and Kuisma, M., 2016. SHIFTing the Support of Entrepreneurship in Eco-Innovation. Summary of results and recommendations from the Eco-Innovera project SHIFT. Berlin, Helsinki, Linköping University: SHIFT.

Fonseca, S. A., and Jabbour, C. J. C., 2012. Assessment of business incubators' green performance: A framework and its application to Brazilian cases. Technovation, 32(2), 122132.

Gabarret, I., Jaouen, A., Nakara, W. A., and Vedel, B., 2014. Why are small public incubators 'lagging behind'? Learning from disability in the selection practices of a French incubator. International Journal of Entrepreneurship and Small Business 58, 23(4), 456-477. 


\section{Incubator specialization and size}

Gerlach, S., \& Brem, A. (2015). What determines a successful business incubator? Introduction to an incubator guide. International Journal of Entrepreneurial Venturing, 7(3), 286-307.

Hansen, M.T., Chesbrough, H.W., Nohria, N., Sull, D.S., 2000. Networked incubators: hothouses of the new economy. Harvard Business Review 78, 74-84.

Hayter, C. S. 2016., A trajectory of early-stage spinoff success: the role of knowledge intermediaries within an entrepreneurial university ecosystem. Small Business Economics, 47(3), 633-656.

Hernández, R., and Carrà, G., 2016. A conceptual approach for business incubator interdependencies and sustainable development. Agriculture and Agricultural Science Procedia, 8, 718-724.

Hsieh, H. F., and Shannon, S. E., 2005. Three approaches to qualitative content analysis. Qualitative health research, 15(9), 1277-1288.

Grimaldi, R., and Grandi, A., 2005. Business incubators and new venture creation: an assessment of incubating models. Technovation, 25(2), 111-121.

Klingbeil, C., \& Semrau, T. 2017. For whom size matters-the interplay between incubator size, tenant characteristics and tenant growth. Industry and Innovation, 24(7), 735-752.

Klofsten, M., \& Bienkowska, D. 2019. Business incubators within entrepreneurial ecosystems - sustainability aspects of new venture support and development. In S. Mian, W. Lamine, \& M. Klofsten (Eds.), International Handbook of Research on Business and Technology Incubation. Edward Elgar.

Klofsten, M., Fayolle, A., Guerrero, M., Mian, S., Urbano, D., \& Wright, M., 2018. The entrepreneurial university as driver for economic growth and social change-Key strategic challenges. Technological Forecasting and Social Change.

Kreusel, N., Roth, N., \& Brem, A. (2018). European business venturing in times of digitisation-an analysis of for-profit business incubators in a triple helix context. International Journal of Technology Management, 76(1-2), 104-136.

Lamine, W., Mian, S., Fayolle, A., Wright, M., Klofsten, M. and Etzkowitz, H., 2016. Technology business incubation mechanisms and sustainable regional development. Journal of Technology Transfer, Published online: 10 December 2016.

Lobosco, A., Maccari, E. A., Costa, P. R. D., \& Almeida, M. I. R. D. (2019). Proposed business model for the sustainability of technology business incubators in Brazil and Portugal. International Journal of Entrepreneurship and Innovation Management, 23(2), 97-141.

Lundqvist, M. A., 2014. The importance of surrogate entrepreneurship for incubated Swedish technology ventures. Technovation, 34(2), 93-100. 
Lukeš, M., Longo, M. C., \& Zouhar, J. 2019. Do business incubators really enhance entrepreneurial growth? Evidence from a large sample of innovative Italian start-ups. Technovation, 82-82, 25-34.

Mason, C., and Brown, R., 2014. Entrepreneurial ecosystems and growth oriented entrepreneurship. Final Report to OECD, Paris. ISO 690.

Mayring, P., 2000. Qualitative Content Analysis. Forum Qualitative Sozialforschung / Forum: Qualitative Social Research, 1(2), 20, 1-10.

McAdam, M., and Marlow, S., 2011. Sense and sensibility: The role of business incubator client advisors in assisting high-technology entrepreneurs to make sense of investment readiness status. Entrepreneurship \& Regional Development, 23(7-8), 449-468.

M'Chirgui, Z., Lamine, W., Mian, S., \& Fayolle, A. (2018. University technology commercialization through new venture projects: an assessment of the French regional incubator program. The Journal of Technology Transfer, 43(5), 1142-1160.

McKelvie, A., Brattström, A., \& Wennberg, K. 2017. How young firms achieve growth: reconciling the roles of growth motivation and innovative activities. Small Business Economics, 49(2), 273-293.

Meyer, M., 2003. Academic entrepreneurs or entrepreneurial academics? Research-based ventures and public support mechanisms. R\&D Management, 33(2), 107-115.

Mian, S. A., 1996. Assessing value-added contributions of university technology business incubators to tenant firms. Research policy, 25(3), 325-335.

Mian, S. A., 1997. Assessing and managing the university technology business incubator: an integrative framework. Journal of Business Venturing, 12(4), 251-285.

McGowan, P., Cooper, S., van der Sijde, P., Agnete Alsos, G., Hytti, U., and Ljunggren, E., 2011. Stakeholder theory approach to technology incubators. International Journal of Entrepreneurial Behavior \& Research, 17(6): 607-625.

OECD., (2013) Green entrepreneurship, Eco-innovation and SMEs, Final report. CFE/SME (2011)9/FINAL, Paris: Organization for Economic Co-operation and Development.

Phan, P.H., Siegel, D.S., and Wright, M., 2005. Science parks and incubators: observations, synthesis and future research. Journal of Business Venturing, 20, 165-182.

Phillips, F., 2018. The sad state of entrepreneurship in America: What educators can do about it. Technological Forecasting and Social Change, 129, 12-15.

Potts, T., 2010. The natural advantage of regions: linking sustainability, innovation, and regional development in Australia. Journal of Cleaner Production, 18(8), 713-725.

Redondo, M., \& Camarero, C. 2019. Social Capital in University Business Incubators: dimensions, antecedents and outcomes. International Entrepreneurship and Management Journal, 15(2), 599-624. 


\section{Incubator specialization and size}

Sandström, C., Wennberg, K., Wallin, M. W., and Zherlygina, Y., 2016. Public policy for academic entrepreneurship initiatives: a review and critical discussion. Journal of Technology Transfer.

Sharif, M. N. 2012. Technological innovation governance for winning the future. Technological forecasting and Social Change, 79(3), 595-604.

Schwartz, M., and Hornych, C., 2008. Specialization as strategy for business incubators: An assessment of the Central German Multimedia Center. Technovation, 28(7), 436-449.

Schwartz, M., \& Hornych, C. 2010. Cooperation patterns of incubator firms and the impact of incubator specialization: Empirical evidence from Germany. Technovation, 30(9-10), 485495.

Schwartz, M., and Hornych, C., 2012. Specialization versus diversification: perceived benefits of different business incubation models. International Journal of Entrepreneurship and Innovation Management, 15(3), 177-197.

Scillitoe, J. L., and Chakrabarti, A. K., 2010. The role of incubator interactions in assisting new ventures. Technovation, 30(3), 155-167.

Sentana, E., González, R., Gascó, J and LLopis, J., 2017. The social profitability of business incubators: a measurement proposal. Entrepreneurship \& Regional Development, 29(1-2), 116-136.

Soetanto, D. P., and Jack, S. L., 2013. Business incubators and the networks of technologybased firms. Journal of Technology Transfer, 38(4), 432-453.

Soetanto, D., and Jack, S., 2016. The impact of university-based incubation support on the innovation strategy of academic spin-offs. Technovation, 50, 25-40.

Somsuk, N., \& Laosirihongthong, T., 2014. A fuzzy AHP to prioritize enabling factors for strategic management of university business incubators: Resource-based view. Technological Forecasting and Social Change, 85, 198-210.

Smilor, R. W., 1987. Managing the incubator system: critical success factors to accelerate new company development. IEEE transactions on Engineering Management, 3, 146-155.

Stuart, T., and Sorenson, O., 2003. The geography of opportunity: spatial heterogeneity in founding rates and the performance of biotechnology firms. Research policy, 32(2), 229-253.

Sung, T. K., Gibson, D. V., \& Kang, B. S., 2003. Characteristics of technology transfer in business ventures: the case of Daejeon, Korea. Technological Forecasting and Social Change, 70(5), 449-466.

Vanderstraeten, J., and Matthyssens, P., 2012. Service-based differentiation strategies for business incubators: Exploring external and internal alignment. Technovation, 32(12), 656670. 
Volkmann, C., Fichter, K., Klofsten, M., \& Audretsch, D. B. (2019). Sustainable entrepreneurial ecosystems: an emerging field of research. Small Business Economics, 1-9.

von Zedtwitz M., and Grimaldi, R., 2006. Are service profiles incubator-specific? Results from an empirical investigation in Italy. Journal of Technology Transfer, 31(4), 459-468.

Wiklund, J., Davidsson, P., \& Delmar, F. 2003. What do they think and feel about growth? An expectancy-value approach to small business managers' attitudes towards growth. Entrepreneurship Theory \& Practice, 26: 247-270.

Wikman, A., 2006. Reliability, validity and true values in surveys. Social Indicators Research, 78(1), 85-110.

Xiao, L and North, D., 2017. The role of Technological Business Incubators in supporting business innovation in China: a case of regional adaptability? Entrepreneurship \& Regional Development, 29(1-2), 1-29.

Figure 1: Perceived challenge in recruiting incubator tenants

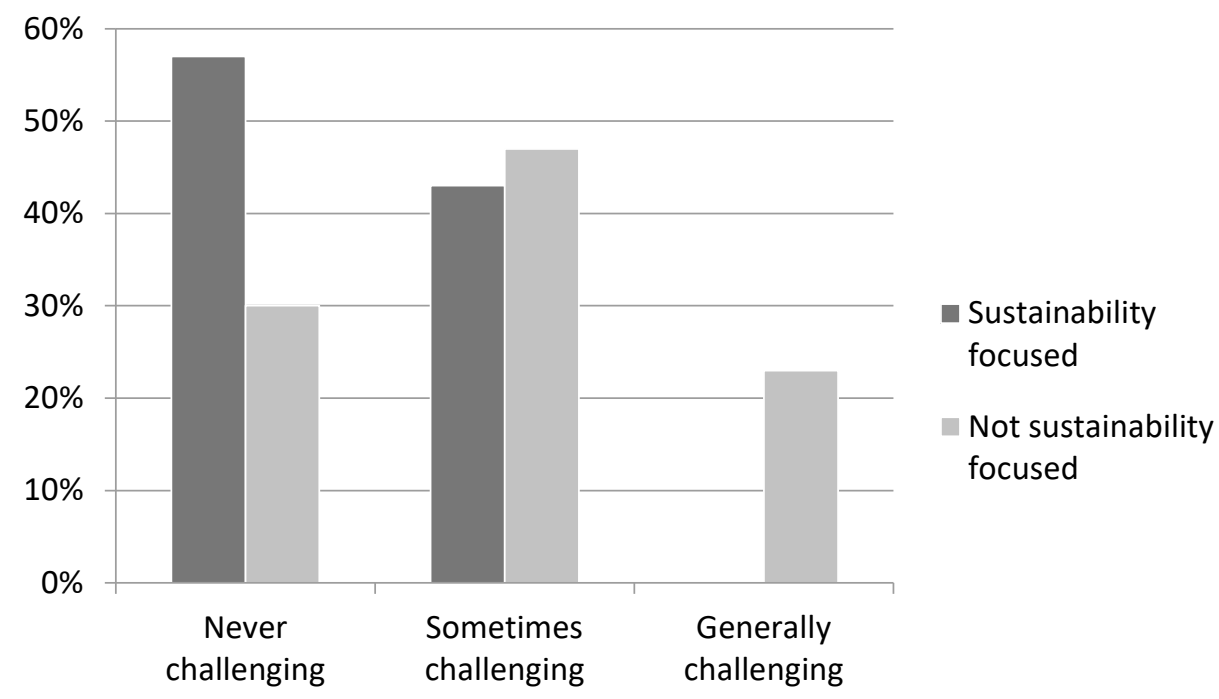




\section{Incubator specialization and size}

Table 1: Descriptive statistics and correlations

\begin{tabular}{|c|c|c|c|c|c|c|c|c|c|}
\hline & Variable & Mean & $\begin{array}{l}\text { Standard } \\
\text { Deviation }\end{array}$ & 1 & 2 & 3 & 4 & 5 & 6 \\
\hline 1 & Tenants $^{\mathrm{a}}$ & 31.84 & 29.22 & & & & & & \\
\hline 2 & Challenge $^{b}$ & 1.9 & 0.73 & $-0.38^{* * *}$ & & & & & \\
\hline 3 & University $^{\mathrm{c}}$ & 0.32 & 0.47 & $0.26^{* *}$ & -0.13 & & & & \\
\hline 4 & Regional $^{\mathrm{c}}$ & 0.57 & 0.50 & $-0.29^{* * *}$ & 0.08 & 0.12 & & & \\
\hline 5 & Industry $^{c}$ & 0.54 & 0.50 & 0.09 & -0.00 & -0.12 & 0.13 & & \\
\hline 6 & Sustain $^{c}$ & 0.16 & 0.37 & $0.32^{* * *}$ & $-0.26^{* *}$ & 0.08 & $-0.23^{* *}$ & 0.09 & \\
\hline 7 & Finland $^{\mathrm{c}}$ & 0.11 & 0.32 & $-0.25^{* *}$ & 0.14 & 0.03 & $0.32^{* * *}$ & 0.07 & -0.06 \\
\hline 8 & Sweden ${ }^{c}$ & 0.21 & 0.41 & $-0.21^{* *}$ & -0.00 & 0.05 & $0.19^{*}$ & -0.04 & -0.14 \\
\hline 9 & Germany $^{c}$ & 0.68 & 0.47 & $0.35^{* * *}$ & -0.09 & -0.07 & $-0.38^{* * *}$ & -0.01 & 0.16 \\
\hline
\end{tabular}

${ }^{a}$ Count variable, number of tenants.

b Ordinal variable, mean and SD have no strict meaning, 32\% "never challenging", $46 \%$ "sometimes challenging", and 22\% "generally challenging".

${ }^{\mathrm{c}}$ Dichotomous variable, mean corresponds to proportion in the sample. 
Incubator specialization and size

Table 2: OLS regression on tenant size

\begin{tabular}{|c|c|c|c|}
\hline & Coefficient & $\begin{array}{c}\text { Standard } \\
\text { Error }\end{array}$ & \\
\hline University & 18.8 & $(5.9)$ & $* * *$ \\
\hline Regional & -10.5 & $(6.2)$ & $*$ \\
\hline Industry & 8.3 & (5.6) & \\
\hline Sustain & 15.8 & (7.8) & $* *$ \\
\hline Sweden ${ }^{a}$ & 7.5 & $(10.0)$ & \\
\hline Germany $^{a}$ & 21.9 & $(9.3)$ & $* *$ \\
\hline Constant & 8.5 & $(10.6)$ & \\
\hline $\mathrm{F}$ & .31 & & \\
\hline $\mathrm{R}^{2}$ & .26 & & \\
\hline$F(6,80)=$ & 5.93 & & $* * *$ \\
\hline$N$ & 89 & & \\
\hline
\end{tabular}




\section{Incubator specialization and size}

\section{Appendix 1: Prior studies of incubators, with a specific focus on size and specialization}

We conducted a formal literature overview through Boolean search words in the databases Web of Science, ABI/Inform and EBSCO, searching for papers with "incubator" in the title, keywords, and/or abstract. We delimited the search to papers in the main entrepreneurship and innovation journals ${ }^{4}$, published after the year 2000. This revealed 137 papers, listed below in Table A1. We then searched all these papers for the words "size" and/or "specialization" in the title, keywords, and/or abstract. This revealed only five papers, which we read in detail and compared our research question, data, and results to. None of these papers had any resemblance in research question, nor sought to model predictors of incubator size like this paper does:

1. Schwartz, M. \& Hornych, C. Cooperation patterns of incubator firms and the impact of incubator specialization: Empirical evidence from Germany. Technovation - SeptemberOctober 2010.

2. Lukes, M., Longo, M.C. \& Zouhar, J. Do business incubators really enhance entrepreneurial growth? Evidence from a large sample of innovative Italian start-ups. Technovation - April-May 2019

3. Sharif, M.N. Technological innovation governance for winning the future. Technological Forecasting and Social Change. - March 2012

4. Schwartz, M. \& Hornych, C. Specialization as strategy for business incubators: An assessment of the Central German Multimedia Center. Technovation - July 2008 5. Klingbeil, C. \& Semrau, T. For whom size matters - the interplay between incubator size, tenant characteristics and tenant growth. Industry and Innovation - January 2017.

\section{Table A1: Papers on incubators published after 2000 in the main entrepreneurship and} innovation journals

1. Aaboen, L. (2009). Explaining incubators using firm analogy. Technovation, 29(10), 657-670.

2. Abetti, P. A. (2004). Government-supported incubators in the Helsinki region, Finland: infrastructure, results, and best practices. The Journal of Technology Transfer, 29(1), 19-40.

3. Adegbite, O. (2001). Business incubators and small enterprise development: the Nigerian experience. Small Business Economics, 17(3), 157-166.

4. Aernoudt, R. (2004). Incubators: tool for entrepreneurship? Small business economics, 23(2), 127-135.

5. Aerts, K., Matthyssens, P., \& Vandenbempt, K. (2007). Critical role and screening practices of European business incubators. Technovation, 27(5), 254-267.

6. Ahmad, A. J., \& Thornberry, C. (2018). On the structure of business incubators: de-coupling issues and the mis-alignment of managerial incentives. The Journal of Technology Transfer, 43(5), 1190-1212.

7. Agnolucci, P., \& McDowall, W. (2007). Technological change in niches: auxiliary power units and the hydrogen economy. Technological Forecasting and Social Change, 74(8), 1394-1410.

8. Baglieri, D., Baldi, F., \& Tucci, C. L. (2018). University technology transfer office business models: One size does not fit all. Technovation, 76, 51-63.

9. Baraldi, E., \& Havenvid, M. I. (2016). Identifying new dimensions of business incubation: A multi-level analysis of Karolinska Institute's incubation system. Technovation, 50, 53-68.

\footnotetext{
${ }^{4}$ Entrepreneurship: Theory and Practice, Journal of Business Venturing, International Small Business Journal, Journal of Small Business Management, Small Business Economics, Entrepreneurship and Regional Development, Strategic Entrepreneurship Journal, Technological Forecasting and Social Change, Research Policy, Industrial and Corporate Change, Technovation, R\&D management, Journal of Technology Transfer, Industry \& Innovation
} 
10. Barbero, J. L., Casillas, J. C., Ramos, A., \& Guitar, S. (2012). Revisiting incubation performance: How incubator typology affects results. Technological Forecasting and Social Change, 79(5), 888-902.

11. Barbero, J. L., Casillas, J. C., Wright, M., \& Garcia, A. R. (2014). Do different types of incubators produce different types of innovations? The Journal of Technology Transfer, 39(2), 151-168.

12. Becker, B., \& Gassmann, O. (2006). Corporate incubators: industrial R\&D and what universities can learn from them. The Journal of Technology Transfer, 31(4), 469-483.

13. Bendell, B. L., Sullivan, D. M., \& Marvel, M. R. (2019). A Gender-Aware Study of Self-Leadership Strategies among High-Growth Entrepreneurs. Journal of Small Business Management, 57(1), 110-130.

14. Bergek, A., \& Norrman, C. (2008). Incubator best practice: A framework. Technovation, 28(1-2), 20-28.

15. Biraglia, A., \& Kadile, V. (2017). The role of entrepreneurial passion and creativity in developing entrepreneurial intentions: Insights from American homebrewers. Journal of Small Business Management, 55(1), 170-188.

16. Breznitz, S. M., Clayton, P. A., Defazio, D., \& Isett, K. R. (2018). Have you been served? The impact of university entrepreneurial support on start-ups' network formation. The Journal of Technology Transfer, 43(2), 343-367.

17. Bruneel, J., Ratinho, T., Clarysse, B., \& Groen, A. (2012). The Evolution of Business Incubators: Comparing demand and supply of business incubation services across different incubator generations. Technovation, 32(2), 110-121.

18. Bøllingtoft, A. (2012). The bottom-up business incubator: Leverage to networking and cooperation practices in a self-generated, entrepreneurial-enabled environment. Technovation, 32(5), 304-315.

19. Bøllingtoft, A., \& Ulhøi, J. P. (2005). The networked business incubator-leveraging entrepreneurial agency?. Journal of Business Venturing, 20(2), 265-290.

20. Carayannis, E. G., Kassicieh, S. K., \& Radosevich, R. (2000). Strategic alliances as a source of early-stage seed capital in new technology-based firms. Technovation, 20(11), 603-615.

21. Carayannis, E. G., Popescu, D., Sipp, C., \& Stewart, M. (2006). Technological learning for entrepreneurial development (TL4ED) in the knowledge economy (KE): case studies and lessons learned. Technovation, 26(4), 419-443.

22. Carayannis, E. G., \& von Zedtwitz, M. (2005). Architecting gloCal (global-local), real-virtual incubator networks (G-RVINs) as catalysts and accelerators of entrepreneurship in transitioning and developing economies: lessons learned and best practices from current development and business incubation practices. Technovation, 25(2), 95-110.

23. Chan, K. F., \& Lau, T. (2005). Assessing technology incubator programs in the science park: the good, the bad and the ugly. Technovation, 25(10), 1215-1228.

24. Chen, M. H., \& Wang, M. C. (2008). Social networks and a new venture's innovative capability: the role of trust within entrepreneurial teams. $R \& D$ Management, 38(3), 253-264.

25. Clarysse, B., Wright, M., Lockett, A., Van de Velde, E., \& Vohora, A. (2005). Spinning out new ventures: a typology of incubation strategies from European research institutions. Journal of Business Venturing, 20(2), 183-216.

26. Clausen, T., \& Korneliussen, T. (2012). The relationship between entrepreneurial orientation and speed to the market: The case of incubator firms in Norway. Technovation, 32(9-10), 560-567.

27. Conceição, O., Faria, A. P., \& Fontes, M. (2017). Regional variation of academic spinoffs formation. The Journal of Technology Transfer, 42(3), 654-675.

28. Colombo, M. G., \& Delmastro, M. (2002). How effective are technology incubators?: Evidence from Italy. Research Policy, 31(7), 1103-1122.

29. Cooper, C. E., Hamel, S. A., \& Connaughton, S. L. (2012). Motivations and obstacles to networking in a university business incubator. The Journal of Technology Transfer, 37(4), 433-453.

30. Cooper, S. Y., \& Park, J. S. (2008). The impact of incubator' organizations on opportunity recognition and technology innovation in new, entrepreneurial high-technology ventures. International Small Business Journal, 26(1), 27-56.

31. Croce, A., Grilli, L., \& Murtinu, S. (2014). Venture capital enters academia: An analysis of universitymanaged funds. The Journal of Technology Transfer, 39(5), 688-715.

32. Cumming, D. J., \& Fischer, E. (2012). Publicly funded business advisory services and entrepreneurial outcomes. Research Policy, 41(2), 467-481.

33. Cumming, D., Werth, J. C., \& Zhang, Y. (2019). Governance in entrepreneurial ecosystems: venture capitalists vs. technology parks. Small Business Economics, 52(2), 455-484.

34. Cunningham, J. A., \& O’Reilly, P. (2018). Macro, meso and micro perspectives of technology transfer. The Journal of Technology Transfer, 43(3), 545-557.

35. Dalmarco, G., Hulsink, W., \& Blois, G. V. (2018). Creating entrepreneurial universities in an emerging economy: Evidence from Brazil. Technological Forecasting and Social Change, 135, 99-111. 
36. Davenport, S., Carr, A., \& Bibby, D. (2002). Leveraging talent: spin-off strategy at Industrial Research. R\&D Management, 32(3), 241-254.

37. Díez-Vial, I., \& Montoro-Sánchez, Á. (2016). How knowledge links with universities may foster innovation: The case of a science park. Technovation, 50, 41-52.

38. Durão, D., Sarmento, M., Varela, V., \& Maltez, L. (2005). Virtual and real-estate science and technology parks: a case study of Taguspark. Technovation, 25(3), 237-244.

39. Ebbers, J. J. (2014). Networking behavior and contracting relationships among entrepreneurs in business incubators. Entrepreneurship Theory and Practice, 38(5), 1-23.

40. Ebbers, J., \& Stam, W. (2019, July). The Value of Perceived and Actual Intra-Incubator Networks and Firm Performance. In Academy of Management Proceedings (Vol. 2019, No. 1, p. 12109). Briarcliff Manor, NY 10510: Academy of Management.

41. Eveleens, C. P., van Rijnsoever, F. J., \& Niesten, E. M. (2017). How network-based incubation helps start-up performance: a systematic review against the background of management theories. The Journal of Technology Transfer, 42(3), 676-713.

42. Etzkowitz, H., de Mello, J. M. C., \& Almeida, M. (2005). Towards “meta-innovation” in Brazil: The evolution of the incubator and the emergence of a triple helix. Research Policy, 34(4), 411-424.

43. Fernández-Alles, M., Camelo-Ordaz, C., \& Franco-Leal, N. (2015). Key resources and actors for the evolution of academic spin-offs. The Journal of Technology Transfer, 40(6), 976-1002.

44. Ferrary, M. (2008). Strategic spin-off: a new incentive contract for managing R\&D researchers. The journal of technology transfer, 33(6), 600-618.

45. Festel, G. (2013). Academic spin-offs, corporate spin-outs and company internal start-ups as technology transfer approach. The Journal of Technology Transfer, 38(4), 454-470.

46. Fini, R., Grimaldi, R., Santoni, S., \& Sobrero, M. (2011). Complements or substitutes? The role of universities and local context in supporting the creation of academic spin-offs. Research Policy, 40(8), $1113-1127$.

47. Fonseca, S. A., \& Jabbour, C. J. C. (2012). Assessment of business incubators' green performance: A framework and its application to Brazilian cases. Technovation, 32(2), 122-132.

48. Ford, S., Garnsey, E., \& Probert, D. (2010). Evolving corporate entrepreneurship strategy: technology incubation at Philips. R\&D Management, 40(1), 81-90.

49. Galbraith, B., McAdam, R., \& Cross, S. E. (2019). The Evolution of the Incubator: Past, Present, and Future. IEEE Transactions on Engineering Management.

50. van Geenhuizen, M., \& Soetanto, D. P. (2009). Academic spin-offs at different ages: A case study in search of key obstacles to growth. Technovation, 29(10), 671-681.

51. George, G., Zahra, S. A., \& Wood Jr, D. R. (2002). The effects of business-university alliances on innovative output and financial performance: a study of publicly traded biotechnology companies. Journal of business Venturing, 17(6), 577-609.

52. Gerlach, S., \& Brem, A. (2015). What determines a successful business incubator? Introduction to an incubator guide. International Journal of Entrepreneurial Venturing, 7(3), 286-307.

53. Gibson, D. V., \& Naquin, H. (2011). Investing in innovation to enable global competitiveness: The case of Portugal. Technological Forecasting and Social Change, 78(8), 1299-1309.

54. Gimmon, E., \& Levie, J. (2010). Founder's human capital, external investment, and the survival of new high-technology ventures. Research Policy, 39(9), 1214-1226.

55. Gkypali, A., Kokkinos, V., Bouras, C., \& Tsekouras, K. (2016). Science parks and regional innovation performance in fiscal austerity era: Less is more?. Small Business Economics, 47(2), 313-330.

56. Grimaldi, R., \& Grandi, A. (2005). Business incubators and new venture creation: an assessment of incubating models. Technovation, 25(2), 111-121.

57. Guerrero, M., Urbano, D., Cunningham, J. A., \& Gajon, E. (2018). Determinants of Graduates' Start-Ups Creation across a Multi-Campus Entrepreneurial University: The Case of Monterrey Institute of Technology and Higher Education. Journal of Small Business Management, 56(1), 150-178.

58. Guerrero, M., Urbano, D., Cunningham, J., \& Organ, D. (2014). Entrepreneurial universities in two European regions: A case study comparison. The journal of Technology Transfer, 39(3), 415-434.

59. Gwebu, K. L., Sohl, J., \& Wang, J. (2019). Differential performance of science park firms: an integrative model. Small Business Economics, 52(1), 193-211.

60. Hackett, S. M., \& Dilts, D. M. (2008). Inside the black box of business incubation: Study B-scale assessment, model refinement, and incubation outcomes. The Journal of Technology Transfer, 33(5), 439471.

61. Hayter, C. S. (2016). A trajectory of early-stage spinoff success: the role of knowledge intermediaries within an entrepreneurial university ecosystem. Small Business Economics, 47(3), 633-656.

62. Hobbs, K. G., Link, A. N., \& Scott, J. T. (2017). Science and technology parks: an annotated and analytical literature review. The Journal of Technology Transfer, 42(4), 957-976. 
63. Hsu, C. W., \& Chiang, H. C. (2001). The government strategy for the upgrading of industrial technology in Taiwan. Technovation, 21(2), 123-132.

64. Kirchberger, M. A., \& Pohl, L. (2016). Technology commercialization: a literature review of success factors and antecedents across different contexts. The Journal of Technology Transfer, 41(5), 1077-1112.

65. Kihlgren, A. (2003). Promotion of innovation activity in Russia through the creation of science parks: the case of St. Petersburg (1992-1998). Technovation, 23(1), 65-76.

66. Klofsten, M., Fayolle, A., Guerrero, M., Mian, S., Urbano, D., \& Wright, M. (2019). The entrepreneurial university as driver for economic growth and social change-Key strategic challenges. Technological Forecasting and Social Change, 141, 149-158.

67. Kreusel, N., Roth, N., \& Brem, A. (2018). European business venturing in times of digitisation-an analysis of for-profit business incubators in a triple helix context. International Journal of Technology Management, 76(1-2), 104-136.

68. Kroll, H., \& Liefner, I. (2008). Spin-off enterprises as a means of technology commercialisation in a transforming economy-Evidence from three universities in China. Technovation, 28(5), 298-313.

69. Lamine, W., Mian, S., Fayolle, A., Wright, M., Klofsten, M., \& Etzkowitz, H. (2018). Technology business incubation mechanisms and sustainable regional development. The Journal of Technology Transfer, 43(5), 1121-1141.

70. Lamperti, F., Mavilia, R., \& Castellini, S. (2017). The role of Science Parks: a puzzle of growth, innovation and R\&D investments. The Journal of Technology Transfer, 42(1), 158-183.

71. Lasrado, V., Sivo, S., Ford, C., O’Neal, T., \& Garibay, I. (2016). Do graduated university incubator firms benefit from their relationship with university incubators? The Journal of Technology Transfer, 41(2), 205-219.

72. Latorre, M. P., Hermoso, R., \& Rubio, M. A. (2017). A novel network-based analysis to measure efficiency in science and technology parks: the ISA framework approach. The Journal of Technology Transfer, 42(6), 1255-1275.

73. Latouche, P. (2019). Open Innovation: Corporate Incubator. John Wiley \& Sons.

74. Lee, S. S., \& Osteryoung, J. S. (2004). A comparison of critical success factors for effective operations of university business incubators in the United States and Korea. Journal of small business management, 42(4), 418-426.

75. Lerner, M., \& Haber, S. (2001). Performance factors of small tourism ventures: The interface of tourism, entrepreneurship and the environment. Journal of business venturing, 16(1), 77-100.

76. Liberati, D., Marinucci, M., \& Tanzi, G. M. (2016). Science and technology parks in Italy: main features and analysis of their effects on the firms hosted. The Journal of Technology Transfer, 41(4), 694-729.

77. Lindelöf, P., \& Löfsten, H. (2006). Environmental hostility and firm behavior-An empirical examination of new technology-based firms on science parks. Journal of Small Business Management, 44(3), 386-406.

78. Linton, J. D. (2012). What's hot and what's not: A summary of topics and papers in technology innovation management that are getting attention. Technovation, 12(32), 653-655.

79. Lockett, A., Siegel, D., Wright, M., \& Ensley, M. D. (2005). The creation of spin-off firms at public research institutions: Managerial and policy implications. Research Policy, 34(7), 981-993.

80. Lukeš, M., Longo, M. C., \& Zouhar, J. (2019). Do business incubators really enhance entrepreneurial growth? Evidence from a large sample of innovative Italian start-ups. Technovation, 82, 25-34.

81. Lundqvist, M. A. (2014). The importance of surrogate entrepreneurship for incubated Swedish technology ventures. Technovation, 34(2), 93-100.

82. Löfsten, H., \& Lindelöf, P. (2001). Science parks in Sweden-industrial renewal and development?. R\&D Management, 31(3), 309-322.

83. McAdam, M., \& McAdam, R. (2008). High tech start-ups in University Science Park incubators: The relationship between the start-up's lifecycle progression and use of the incubator's resources. Technovation, 28(5), 277-290.

84. McAdam, R., McAdam, M., \& Brown, V. (2009). Proof of concept processes in UK university technology transfer: an absorptive capacity perspective. $R \& D$ Management, 39(2), 192-210.

85. McAdam, M., McAdam, R., Galbraith, B., \& Miller, K. (2010). An exploratory study of Principal Investigator roles in UK university Proof-of-Concept processes: an Absorptive Capacity perspective. $R \& d$ Management, 40(5), 455-473.

86. M'Chirgui, Z., Lamine, W., Mian, S., \& Fayolle, A. (2018). University technology commercialization through new venture projects: an assessment of the French regional incubator program. The Journal of Technology Transfer, 43(5), 1142-1160.

87. Markman, G. D., Phan, P. H., Balkin, D. B., \& Gianiodis, P. T. (2005). Entrepreneurship and universitybased technology transfer. Journal of Business Venturing, 20(2), 241-263.

88. Marvel, M. (2012). Knowledge acquisition asymmetries and innovation radicalness. Journal of Small Business Management, 50(3), 447-468. 
89. Messeghem, K., Bakkali, C., Sammut, S., \& Swalhi, A. (2018). Measuring nonprofit incubator performance: Toward an adapted balanced scorecard approach. Journal of Small Business Management, 56(4), 658-680.

90. Mian, S., Lamine, W., \& Fayolle, A. (2016). Technology business incubation: An overview of the state of knowledge. Technovation, 50, 1-12.

91. Miller, D. J., \& Acs, Z. J. (2017). The campus as entrepreneurial ecosystem: the University of Chicago. Small Business Economics, 49(1), 75-95.

92. Mora-Valentín, E. M., Ortiz-de-Urbina-Criado, M., \& Nájera-Sánchez, J. J. (2018). Mapping the conceptual structure of science and technology parks. The Journal of Technology Transfer, 43(5), 14101435.

93. Morrish, S. C., Whyte, M. C., \& Miles, M. P. (2019). Incubator mediation in commercialising disruptive innovation. Journal of Strategic Marketing, 27(2), 177-189.

94. Mrkajic, B. (2017). Business incubation models and institutionally void environments. Technovation, 68, 44-55.

95. Munari, F., Pasquini, M., \& Toschi, L. (2015). From the lab to the stock market? The characteristics and impact of university-oriented seed funds in Europe. The Journal of Technology Transfer, 40(6), 948-975.

96. Neck, H. M., Meyer, G. D., Cohen, B., \& Corbett, A. C. (2004). An entrepreneurial system view of new venture creation. Journal of Small Business Management, 42(2), 190-208.

97. Nicolopoulou, K., Karataş-Özkan, M., Vas, C., \& Nouman, M. (2017). An incubation perspective on social innovation: the London Hub-a social incubator. $R \& D$ Management, 47(3), 368-384.

98. Nijssen, E. J., \& Van der Borgh, M. (2017). Beyond the water cooler: using socialization to understand use and impact of networking services on collaboration in a business incubator. $R \& D$ Management, 47(3), 443-457.

99. Nowak, M. J., \& Grantham, C. E. (2000). The virtual incubator: managing human capital in the software industry. Research Policy, 29(2), 125-134.

100.Oakey, R. (2007). Clustering and the R\&D management of high-technology small firms: in theory and practice. $R \& D$ Management, 37(3), 237-248.

101.O'Gorman, C., Byrne, O., \& Pandya, D. (2008). How scientists commercialise new knowledge via entrepreneurship. The Journal of Technology Transfer, 33(1), 23-43.

102.Palmai, Z. (2004). An innovation park in Hungary: INNOTECH of the Budapest University of Technology and Economics. Technovation, 24(5), 421-432.

103.Patton, D., Warren, L., \& Bream, D. (2009). Elements that underpin high-tech business incubation processes. The Journal of Technology Transfer, 34(6), 621-636.

104.Pauwels, C., Clarysse, B., Wright, M., \& Van Hove, J. (2016). Understanding a new generation incubation model: The accelerator. Technovation, 50, 13-24.

105.Phan, P. H., Siegel, D. S., \& Wright, M. (2005). Science parks and incubators: observations, synthesis and future research. Journal of Business Venturing, 20(2), 165-182.

106. Radu Lefebvre, M., \& Redien-Collot, R. (2013). "How to do things with words": The discursive dimension of experiential learning in entrepreneurial mentoring dyads. Journal of Small Business Management, 51(3), 370-393.

107. Ramasamy, B., Chakrabarty, A., \& Cheah, M. (2004). Malaysia's leap into the future: an evaluation of the multimedia super corridor. Technovation, 24(11), 871-883.

108. Ramírez-Alesón, M., \& Fernández-Olmos, M. (2018). Unravelling the effects of Science Parks on the innovation performance of NTBFs. The Journal of Technology Transfer, 43(2), 482-505.

109. Ratinho, T., \& Henriques, E. (2010). The role of science parks and business incubators in converging countries: Evidence from Portugal. Technovation, 30(4), 278-290.

110. Rice, MP. (2000). Co-production of business assistance in business incubators - An exploratory study. Journal of Business Venturing, 17(2), 163-187.

111. Rothaermel, F. T., \& Thursby, M. (2005). University-incubator firm knowledge flows: assessing their impact on incubator firm performance. Research Policy, 34(3), 305-320.

112.Rothaermel, F. T., \& Thursby, M. (2005). Incubator firm failure or graduation? The role of university linkages. Research Policy, 34(7), 1076-1090.

113. Rothschild, L., \& Darr, A. (2005). Technological incubators and the social construction of innovation networks: an Israeli case study. Technovation, 25(1), 59-67.

114.Rubin, T. H., Aas, T. H., \& Stead, A. (2015). Knowledge flow in technological business incubators: evidence from Australia and Israel. Technovation, 41, 11-24.

115.Sá, C., \& Lee, H. (2012). Science, business, and innovation: understanding networks in technology-based incubators. $R \& D$ Management, 42(3), 243-253. 
116.Sandström, C., Wennberg, K., Wallin, M. W., \& Zherlygina, Y. (2018). Public policy for academic entrepreneurship initiatives: a review and critical discussion. The Journal of Technology Transfer, 43(5), 1232-1256.

117.Salvador, E. (2011). Are science parks and incubators good "brand names" for spin-offs? The case study of Turin. The Journal of Technology Transfer, 36(2), 203-232.

118. Schwartz, M. (2009). Beyond incubation: an analysis of firm survival and exit dynamics in the postgraduation period. The Journal of Technology Transfer, 34(4), 403-421.

119. Schwartz, M. (2013). A control group study of incubators' impact to promote firm survival. The Journal of Technology Transfer, 38(3), 302-331.

120.Schwartz, M., \& Hornych, C. (2008). Specialization as strategy for business incubators: An assessment of the Central German Multimedia Center. Technovation, 28(7), 436-449.

121.Schwartz, M., \& Hornych, C. (2010). Cooperation patterns of incubator firms and the impact of incubator specialization: Empirical evidence from Germany. Technovation, 30(9-10), 485-495.

122. Scillitoe, J. L., \& Chakrabarti, A. K. (2010). The role of incubator interactions in assisting new ventures. Technovation, 30(3), 155-167.

123. Sharif, M. N. (2012). Technological innovation governance for winning the future. Technological forecasting and social change, 79(3), 595-604.

124.Soetanto, D. P., \& Jack, S. L. (2013). Business incubators and the networks of technology-based firms. The Journal of Technology Transfer, 38(4), 432-453.

125. Soetanto, D., \& Jack, S. (2016). The impact of university-based incubation support on the innovation strategy of academic spin-offs. Technovation, 50, 25-40.

126. Soetanto, D., \& Jack, S. L. (2018). Slack resources, exploratory and exploitative innovation and the performance of small technology-based firms at incubators. The Journal of Technology Transfer, 43(5), 1213-1231.

127. Soetanto, D., \& van Geenhuizen, M. (2019). Life after incubation: The impact of entrepreneurial universities on the long-term performance of their spin-offs. Technological Forecasting and Social Change, 141, 263-276.

128. Sofouli, E., \& Vonortas, N. S. (2007). S\&T Parks and business incubators in middle-sized countries: the case of Greece. The Journal of Technology Transfer, 32(5), 525-544.

129. Somsuk, N., \& Laosirihongthong, T. (2014). A fuzzy AHP to prioritize enabling factors for strategic management of university business incubators: Resource-based view. Technological Forecasting and Social Change, 85, 198-210.

130.van Stijn, N., van Rijnsoever, F. J., \& van Veelen, M. (2018). Exploring the motives and practices of university-start-up interaction: evidence from Route 128. The Journal of Technology Transfer, 43(3), 674-713.

131. Squicciarini, M. (2009). Science parks: seedbeds of innovation? A duration analysis of firms' patenting activity. Small Business Economics, 32(2), 169-190.

132. Theodoraki, C., Messeghem, K., \& Rice, M. P. (2018). A social capital approach to the development of sustainable entrepreneurial ecosystems: an explorative study. Small Business Economics, 51(1), 153-170.

133.Ubeda, F., Ortiz-de-Urbina-Criado, M., \& Mora-Valentín, E. M. (2019). Do firms located in science and technology parks enhance innovation performance? The effect of absorptive capacity. The Journal of Technology Transfer, 44(1), 21-48.

134.Uy, M. A., Foo, M. D., \& Ilies, R. (2015). Perceived progress variability and entrepreneurial effort intensity: The moderating role of venture goal commitment. Journal of Business Venturing, 30(3), 375389.

135. Vanderstraeten, J., \& Matthyssens, P. (2012). Service-based differentiation strategies for business incubators: Exploring external and internal alignment. Technovation, 32(12), 656-670.

136.Villani, E., Rasmussen, E., \& Grimaldi, R. (2017). How intermediary organizations facilitate universityindustry technology transfer: A proximity approach. Technological Forecasting and Social Change, 114, 86-102.

137.Van Weele, M., van Rijnsoever, F. J., Eveleens, C. P., Steinz, H., van Stijn, N., \& Groen, M. (2018). Start-EU-up! Lessons from international incubation practices to address the challenges faced by Western European start-ups. The Journal of Technology Transfer, 43(5), 1161-1189.

138.van Weele, M., van Rijnsoever, F. J., \& Nauta, F. (2017). You can't always get what you want: How entrepreneur's perceived resource needs affect the incubator's assertiveness. Technovation, 59, 18-33.

139. Wonglimpiyarat, J. (2010). Commercialization strategies of technology: lessons from Silicon Valley. The Journal of Technology Transfer, 35(2), 225-236.

140.Wright, M., Siegel, D. S., \& Mustar, P. (2017). An emerging ecosystem for student start-ups. The Journal of Technology Transfer, 42(4), 909-922. 


\section{Incubator specialization and size}

141.Xiao, L., \& North, D. (2017). The graduation performance of technology business incubators in China's three tier cities: the role of incubator funding, technical support, and entrepreneurial mentoring. The Journal of Technology Transfer, 42(3), 615-634.

142.Zehavi, A., \& Breznitz, D. (2017). Distribution sensitive innovation policies: Conceptualization and empirical examples. Research Policy, 46(1), 327-336.

143.Zou, Y., \& Zhao, W. (2014). Anatomy of Tsinghua University Science Park in China: institutional evolution and assessment. The Journal of Technology Transfer, 39(5), 663-674. 